Acta Crystallographica Section E

Structure Reports

Online

ISSN 1600-5368

\section{Dieuropium(III) silicodimonophosphatediphosphate}

Jamal Bennazha, ${ }^{\text {a,b }}$ Ali Boukhari ${ }^{\text {b }}$ and Elizabeth M. Holt ${ }^{\mathrm{c}}$ *

${ }^{a}$ Département de Chimie, Faculté des Sciences et Techniques, Université Hassan-II, Mohammedia, Morocco, ${ }^{\mathbf{b}}$ Laboratoire de Chimie du Solide Appliquée, Laboratoire Associé Francophone, Département de Chimie, Faculté des Sciences, Université Mohammed-V, Avenue Ibn-Batouta, Rabat, Morocco, and ${ }^{\mathrm{c}}$ Department of Chemistry, Oklahoma State University, Stillwater, Oklahoma 74078, USA

Correspondence e-mail: betsy@biochem.okstate.edu

\section{Key indicators}

Single-crystal X-ray study $T=293 \mathrm{~K}$

Mean $\sigma(\mathrm{Si}-\mathrm{O})=0.006 \AA$

Disorder in main residue

$R$ factor $=0.025$

$w R$ factor $=0.064$

Data-to-parameter ratio $=12.8$

For details of how these key indicators were automatically derived from the article, see http://journals.iucr.org/e.
(C) 2001 International Union of Crystallography Printed in Great Britain - all rights reserved
A new europium(III) silicophosphate, whose formula may be considered to be $\mathrm{Eu}_{2} \mathrm{Si}\left(\mathrm{PO}_{4}\right)_{2}\left(\mathrm{P}_{2} \mathrm{O}_{7}\right)$, has been found to consist of phosphosilicate chains with $\mathrm{Si}-\mathrm{O}-\mathrm{P}-\mathrm{O}-\mathrm{P}-\mathrm{O}-$ Si backbones extending in the $a$ direction. The $\mathrm{P}_{2} \mathrm{O}_{7}$ group and the $\mathrm{Si}$ atom both lie on crystallographic twofold axes. Tetrahedral silicon is further bound to two monophosphate groups. This is a silicophosphate of previously unseen type.

\section{Comment}

The structural literature contains reports of only three silicophosphate materials with +3 charged cations. These contain two distinctly different silicophosphate moieties.

$\mathrm{RuSiP}_{3} \mathrm{O}_{11}$ (Fukuoka et al., 1996) may be seen to exist with $\mathrm{Si}_{2} \mathrm{O}_{7}$ groups sharing each of its six terminal $\mathrm{O}$ atoms with a different $\mathrm{P}_{2} \mathrm{O}_{7}$ group. Each $\mathrm{P}_{2} \mathrm{O}_{7}$ group is seen to share a single $\mathrm{O}$ atom per $\mathrm{PO}_{4}$ tetrahedron with an $\mathrm{Si}_{2} \mathrm{O}_{7}$ group, creating a three-dimensional network of linked tetrahedra which encapsulate $\mathrm{Ru}^{3+}$ cations. $\mathrm{MoSiP}_{3} \mathrm{O}_{11}$ (Leclaire \& Raveau, 1987) shows the same motif, with $\mathrm{Mo}^{3+}$ encapsulated within the three-dimensional network of silicophosphates.

$\mathrm{Mo}_{3} \mathrm{SiP}_{5} \mathrm{O}_{19}$ (Wang et al., 1988) exists with isolated $\left(\mathrm{PO}_{3} \mathrm{O}\right)_{3} \mathrm{SiOSi}\left(\mathrm{OPO}_{3}\right)_{3}$ and $\left(\mathrm{PO}_{3} \mathrm{O}\right)_{3} \mathrm{POP}\left(\mathrm{OPO}_{3}\right)_{3}$ units stacked in columns parallel to the hexagonal $c$ axis. $\mathrm{V}_{3} \mathrm{SiP}_{5} \mathrm{O}_{19}$ (Leclaire et al., 1986) appears to be isostructural with the molybedenum-containing compound of similar formula. $\mathrm{Mo}_{4} \mathrm{Si}_{2} \mathrm{P}_{6} \mathrm{O}_{25}$ (Leclaire et al., 1988) shows a similar motif but with $\left(\mathrm{PO}_{3} \mathrm{O}\right)_{3} \mathrm{SiOSi}\left(\mathrm{OPO}_{3}\right)_{3}$ groups only.

$\mathrm{Eu}_{2} \mathrm{Si}\left(\mathrm{PO}_{4}\right)_{2}\left(\mathrm{P}_{2} \mathrm{O}_{7}\right)$ crystallizes with silicophosphate chains with $\mathrm{Si}-\mathrm{O}-\mathrm{P}-\mathrm{O}-\mathrm{P}-\mathrm{O}$ backbones extending in the $a$ direction (Fig. 1). Tetrahedral silicon is further bound to two monophosphate groups, whereas the $\mathrm{P}$ atoms of the polymeric chain are further bonded to two terminal $\mathrm{O}$ atoms, $\mathrm{O} 21$ and O23 (Fig. 1). Thus, it is a silicophosphate of a previously unseen type.

Atoms O21, O22 and O23 display a 0.46/0.54 disorder with positions $\mathrm{O} 21^{\prime}, \mathrm{O} 22^{\prime}$ and $\mathrm{O} 23^{\prime}$, and are related to them by a $23.3^{\circ}$ rotation about the $\mathrm{P} 2-\mathrm{O} 24$ bond. Atoms $\mathrm{O} 22$ and $\mathrm{O} 22^{\prime}$ lie on a twofold axis.

$\mathrm{Eu}$ atoms are localized between $\mathrm{PO}_{3}$ groups and the two terminal $\mathrm{O}$ atoms of a $\mathrm{P}$ atom of the polymeric chain. $\mathrm{Eu}$ is within bonding distance of each of the disordered positions, $\mathrm{O} 21, \mathrm{O}_{2} 1^{\prime}, \mathrm{O} 23$ and $\mathrm{O}^{\prime} 3^{\prime} . \mathrm{Eu}^{3+}$ is six coordinate [average $\mathrm{Eu}-$

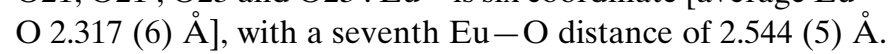
With the inclusion of the seventh distance, the geometry at europium appears to be that of a pentagonal bipyramid. Using bond-valence calculations to ascertain the validity of the
Received 18 February 2000 Accepted 18 January 2001 Online 30 January 2001 


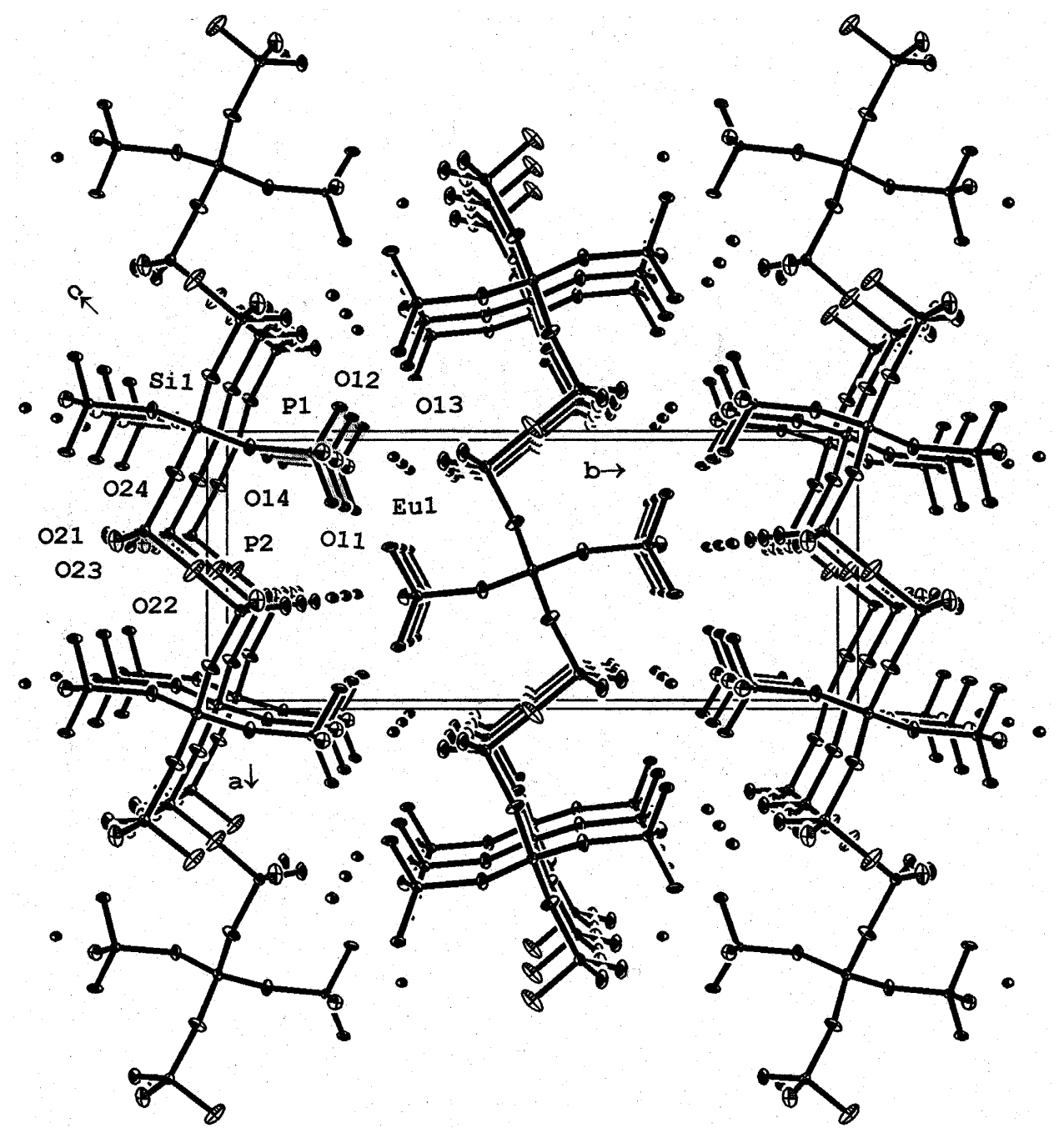

Figure 1

View of dieuropium(III) silicodimonophosphatediphosphate projected on the $a b$ plane. Displacement ellipsoids are shown at the $50 \%$ probability level.

seventh distance (Brown, 1981) leads to a valence bond total of 3.065 using the six Eu-O distances of less than 2.451 (5) $\AA$, but a significantly larger total of $3.352 \AA$ if the seventh distance is included. Both geometry and valence-bond calculations argue that this longer distance is meaningful.

Silicon displays tetrahedral geometry, with an average $\mathrm{Si}-$ O distance of 1.604 (6) А. Phosphorus tetrahedra have average $\mathrm{P}-\mathrm{O}$ distances of 1.511 (11) $\AA$.
Data collection

Syntex $P 4$ four-circle diffractometer $\theta / 2 \theta$ scans

Absorption correction: $\psi$ scan

(XEMP; Siemens, 1990)

$T_{\min }=0.181, T_{\max }=0.357$

1578 measured reflections

1422 independent reflections

1388 reflections with $I>2 \sigma(I)$

$$
\begin{aligned}
& R_{\text {int }}=0.031 \\
& \theta_{\max }=30.0^{\circ} \\
& h=-1 \rightarrow 9 \\
& k=-1 \rightarrow 23 \\
& l=-1 \rightarrow 7 \\
& 3 \text { standard reflections } \\
& \quad \text { every } 97 \text { reflections } \\
& \quad \text { intensity decay: none }
\end{aligned}
$$

\section{Refinement}

Refinement on $F^{2}$

$R\left[F^{2}>2 \sigma\left(F^{2}\right)\right]=0.025$

$w R\left(F^{2}\right)=0.064$

$S=1.07$

1422 reflections

111 parameters

$$
\begin{aligned}
& w=1 /\left[\sigma^{2}\left(F_{o}{ }^{2}\right)+(0.0334 P)^{2}\right. \\
& +1.2737 P] \\
& \text { where } P=\left(F_{o}^{2}+2 F_{c}^{2}\right) / 3 \\
& (\Delta / \sigma)_{\max }=0.012 \\
& \Delta \rho_{\max }=0.01 \mathrm{e}^{-3} \\
& \Delta \rho_{\min }=-0.02 \mathrm{e}^{-3} \\
& \text { Extinction correction: SHELXL97 } \\
& \text { Extinction coefficient: } 0.0030 \text { (4) }
\end{aligned}
$$

$c=5.585(1) \AA$

$V=645.34(19) \AA^{3}$

$\mu=10.30 \mathrm{~mm}^{-1}$

$T=293(2) \mathrm{K}$

Needle, colorless

$Z=2$
$D_{x}=3.581 \mathrm{Mg} \mathrm{m}^{-3}$

$0.15 \times 0.12 \times 0.10 \mathrm{~mm}$ 
Table 1

Selected geometric parameters $\left(\AA{ }^{\circ}\right)$.

\begin{tabular}{|c|c|c|c|}
\hline $\mathrm{Eu} 1-\mathrm{O} 21^{\mathrm{i}}$ & $2.217(18)$ & $\mathrm{Si} 1-\mathrm{O} 13$ & $1.615(5)$ \\
\hline $\mathrm{Eu} 1-\mathrm{O} 21^{\prime i}$ & $2.344(13)$ & $\mathrm{P} 1-\mathrm{O} 11$ & $1.514(5)$ \\
\hline Eu1-O23 & $2.309(15)$ & $\mathrm{P} 1-\mathrm{O} 12$ & $1.523(5)$ \\
\hline $\mathrm{Eu} 1-\mathrm{O} 23^{\prime i \mathrm{i}}$ & $2.240(12)$ & $\mathrm{P} 1-\mathrm{O} 13$ & $1.577(5)$ \\
\hline Eu1-O14 & $2.267(5)$ & $\mathrm{P} 1-\mathrm{O} 14$ & $1.504(5)$ \\
\hline Eu1-O12 iv & $2.349(4)$ & $\mathrm{P} 2-\mathrm{O} 21$ & $1.476(18)$ \\
\hline Eu1-O11 ${ }^{v}$ & $2.360(4)$ & $\mathrm{P} 2-\mathrm{O} 21^{\prime}$ & $1.496(15)$ \\
\hline Eu1-O12 & $2.451(5)$ & $\mathrm{P} 2-\mathrm{O} 22$ & $1.536(5)$ \\
\hline Eu1-O11 & $2.544(5)$ & $\mathrm{P} 2-\mathrm{O} 22^{\prime}$ & $1.547(5)$ \\
\hline $\mathrm{Si} 1-\mathrm{O} 24$ & $1.593(6)$ & $\mathrm{P} 2-\mathrm{O} 23$ & $1.520(14$ \\
\hline $\mathrm{Si} 1-\mathrm{O} 24^{\mathrm{vi}}$ & $1.593(6)$ & $\mathrm{P} 2-\mathrm{O} 23^{\prime}$ & $1.436(12)$ \\
\hline $\mathrm{Si} 1-\mathrm{O} 13^{\mathrm{vi}}$ & $1.615(5)$ & $\mathrm{P} 2-\mathrm{O} 24$ & $1.568(5)$ \\
\hline $\mathrm{O} 21^{\mathrm{i}}-\mathrm{Eu} 1-\mathrm{O} 14^{\mathrm{iii}}$ & $82.2(5)$ & $\mathrm{O} 21^{\prime i}-\mathrm{Eu} 1-\mathrm{O} 11$ & $149.4(4)$ \\
\hline $\mathrm{O} 23^{\text {ii }}-\mathrm{Eu} 1-\mathrm{O} 14^{\mathrm{iii}}$ & $169.9(4)$ & O12-Eu1-O11 & $57.32(14$ \\
\hline $\mathrm{O} 21^{\mathrm{i}}-\mathrm{Eu} 1-\mathrm{O} 23^{\mathrm{ii}}$ & $87.6(5)$ & $\mathrm{O} 24-\mathrm{Si} 1-\mathrm{O} 24^{\mathrm{vi}}$ & $103.6(5)$ \\
\hline $\mathrm{O} 14^{\mathrm{iii}}-\mathrm{Eu} 1-\mathrm{O} 23^{\mathrm{ii}}$ & $169.7(4)$ & $\mathrm{O} 24-\mathrm{Si} 1-\mathrm{O} 13^{\mathrm{vi}}$ & $112.5(3)$ \\
\hline $\mathrm{O} 21^{\mathrm{i}}-\mathrm{Eu} 1-\mathrm{O} 12^{\mathrm{iv}}$ & $78.4(5)$ & $\mathrm{O} 24^{\mathrm{vi}}-\mathrm{Si} 1-\mathrm{O} 13^{\mathrm{vi}}$ & $111.4(3)$ \\
\hline $\mathrm{O} 23^{\prime i \mathrm{ii}}-\mathrm{Eu} 1-\mathrm{O} 12^{\mathrm{iv}}$ & $82.1(4)$ & $\mathrm{O} 24-\mathrm{Si} 1-\mathrm{O} 13$ & $111.4(3)$ \\
\hline $\mathrm{O} 14^{\mathrm{iii}}-\mathrm{Eu} 1-\mathrm{O} 12^{\mathrm{iv}}$ & $88.8(2)$ & $\mathrm{O} 24^{\mathrm{vi}}-\mathrm{Si} 1-\mathrm{O} 13$ & $112.5(3)$ \\
\hline $\mathrm{O} 23^{\mathrm{ii}}-\mathrm{Eu} 1-\mathrm{O} 12^{\mathrm{iv}}$ & $88.0(5)$ & $\mathrm{O} 13^{\mathrm{vi}}-\mathrm{Si} 1-\mathrm{O} 13$ & $105.6(4)$ \\
\hline $\mathrm{O} 21^{\mathrm{i}}-\mathrm{Eu} 1-\mathrm{O} 11^{\mathrm{v}}$ & $87.9(5)$ & $\mathrm{O} 14-\mathrm{P} 1-\mathrm{O} 11$ & $115.4(3)$ \\
\hline $\mathrm{O} 23^{\text {ii }}-\mathrm{Eu} 1-\mathrm{O} 11^{\mathrm{v}}$ & $96.4(4)$ & $\mathrm{O} 14-\mathrm{P} 1-\mathrm{O} 12$ & $114.6(3)$ \\
\hline $\mathrm{O} 14^{\mathrm{iii}}-\mathrm{Eu} 1-\mathrm{O} 11^{\mathrm{v}}$ & $93.5(2)$ & $\mathrm{O} 11-\mathrm{P} 1-\mathrm{O} 12$ & $104.2(3)$ \\
\hline $\mathrm{O} 23^{\mathrm{ii}}-\mathrm{Eu} 1-\mathrm{O} 11^{\mathrm{v}}$ & $87.4(5)$ & $\mathrm{O} 14-\mathrm{P} 1-\mathrm{O} 13$ & $107.8(3)$ \\
\hline $\mathrm{O} 12^{\mathrm{iv}}-\mathrm{Eu} 1-\mathrm{O} 11^{\mathrm{v}}$ & $165.72(15)$ & $\mathrm{O} 11-\mathrm{P} 1-\mathrm{O} 13$ & $107.5(3)$ \\
\hline $\mathrm{O} 14^{\mathrm{iii}}-\mathrm{Eu} 1-\mathrm{O} 21^{\mathrm{i}}$ & $95.7(4)$ & $\mathrm{O} 12-\mathrm{P} 1-\mathrm{O} 13$ & $106.8(3)$ \\
\hline $\mathrm{O} 12^{\mathrm{iv}}-\mathrm{Eu} 1-\mathrm{O} 21^{1 \mathrm{i}}$ & $83.9(4)$ & $\mathrm{O} 21-\mathrm{P} 2-\mathrm{O} 23$ & $116.4(8)$ \\
\hline $\mathrm{O} 11^{\mathrm{v}}-\mathrm{Eu} 1-\mathrm{O} 21^{\prime \mathrm{i}}$ & $81.9(4)$ & $\mathrm{O} 21-\mathrm{P} 2-\mathrm{O} 22$ & $108.9(10)$ \\
\hline $\mathrm{O} 21^{\mathrm{i}}-\mathrm{Eu} 1-\mathrm{O} 12$ & $156.9(5)$ & $\mathrm{O} 23-\mathrm{P} 2-\mathrm{O} 22$ & $108.8(11)$ \\
\hline $\mathrm{O} 23^{\prime i i}-\mathrm{Eu} 1-\mathrm{O} 12$ & $83.2(4)$ & $\mathrm{O} 21-\mathrm{P} 2-\mathrm{O} 24$ & $110.7(8)$ \\
\hline $\mathrm{O} 14^{\mathrm{iii}}-\mathrm{Eu} 1-\mathrm{O} 12$ & $98.71(18)$ & $\mathrm{O} 23-\mathrm{P} 2-\mathrm{O} 24$ & $109.6(8)$ \\
\hline $\mathrm{O} 23^{\mathrm{ii}}-\mathrm{Eu} 1-\mathrm{O} 12$ & $91.1(4)$ & $\mathrm{O} 22-\mathrm{P} 2-\mathrm{O} 24$ & $101.5(2)$ \\
\hline $\mathrm{O} 12^{\mathrm{iv}}-\mathrm{Eu} 1-\mathrm{O} 12$ & $124.68(12)$ & $\mathrm{O} 23^{\prime}-\mathrm{P} 2-\mathrm{O} 22^{\prime}$ & $109.0(9)$ \\
\hline $\mathrm{O} 11^{\mathrm{v}}-\mathrm{Eu} 1-\mathrm{O} 12$ & $68.94(15)$ & $\mathrm{O} 21^{\prime}-\mathrm{P} 2-\mathrm{O} 22^{\prime}$ & $109.7(9)$ \\
\hline $\mathrm{O} 21^{\prime i}-\mathrm{Eu} 1-\mathrm{O} 12$ & $148.0(4)$ & $\mathrm{O} 23^{\prime}-\mathrm{P} 2-\mathrm{O} 24$ & $108.4(6)$ \\
\hline $\mathrm{O} 21^{\mathrm{i}}-\mathrm{Eu} 1-\mathrm{O} 11$ & $145.8(5)$ & $\mathrm{O} 23^{\prime}-\mathrm{P} 2-\mathrm{O} 21^{\prime}$ & $118.1(7)$ \\
\hline $\mathrm{O} 23^{\prime i i}-\mathrm{Eu} 1-\mathrm{O} 11$ & $78.3(4)$ & $\mathrm{O} 21^{\prime}-\mathrm{P} 2-\mathrm{O} 24$ & $108.4(6)$ \\
\hline $\mathrm{O} 14^{\mathrm{iii}}-\mathrm{Eu} 1-\mathrm{O} 11$ & 94.34 (18) & $\mathrm{O} 22^{\prime}-\mathrm{P} 2-\mathrm{O} 24$ & $102.2(2)$ \\
\hline $\mathrm{O} 23^{\mathrm{ii}}-\mathrm{Eu} 1-\mathrm{O} 11$ & 93.4 (4) & $\mathrm{P}^{\mathrm{vii}}-\mathrm{O} 22-\mathrm{P} 2$ & $158(2)$ \\
\hline $\mathrm{O} 12^{\mathrm{iv}}-\mathrm{Eu} 1-\mathrm{O} 11$ & $67.52(15)$ & $\mathrm{P} 2-\mathrm{O} 22^{\prime}-\mathrm{P} 2^{\mathrm{vii}}$ & $154.1(16)$ \\
\hline $\mathrm{O} 11^{\mathrm{v}}-\mathrm{Eu} 1-\mathrm{O} 11$ & $126.26(12)$ & & \\
\hline
\end{tabular}

Symmetry codes: (i) $\frac{1}{2}-x, \frac{1}{2}+y, 2-z$; (ii) $\frac{1}{2}-x, \frac{1}{2}+y, 3-z$; (iii) $x, y, z-1$; (iv) $\frac{1}{2}+x, \frac{1}{2}-y, 2-z$; (v) $x-\frac{1}{2}, \frac{1}{2}-y, 2-z$; (vi) $-x,-y, z$; (vii) $1-x,-y, z$.

The orthorhombic cell displayed absences $h 00, h=2 n$ and $0 k 0, k=$ $2 n$, fixing the space group as $P 2{ }_{1} 2{ }_{1} 2$. Disorder of three $\mathrm{O}$ atoms became apparent as refinement progressed. The $\mathrm{P}_{2} \mathrm{O}_{7}$ group exists with a twofold axis passing through the bridging $\mathrm{O}$ atom, which was seen to exist in two positions $\mathrm{O} 22$ and $\mathrm{O} 22^{\prime}$, both on the twofold axis.
While P2 and $\mathrm{O} 24$ were seen in ordered positions, alternate or disordered positions were seen for terminal $\mathrm{O}$ atoms $\mathrm{O} 21\left(\mathrm{O} 21^{\prime}\right)$ and $\mathrm{O} 23\left(\mathrm{O} 23^{\prime}\right)$. O21, O22, $\mathrm{O} 23$ and $\mathrm{O} 24$ form a tetrahedral array about $\mathrm{P} 2$ as do $\mathrm{O} 21^{\prime}, \mathrm{O} 22^{\prime} \mathrm{O} 23^{\prime}$ and $\mathrm{O} 24$. The disorder may be understood in terms of an approximately $22^{\circ}$ rotation about the $\mathrm{P} 2-\mathrm{O} 24$ (and the $\mathrm{P} 2 a-\mathrm{O} 24 a$ bond related by the twofold axis) corresponding to the bridging $\mathrm{O}$ atom being 'up' or 'down' and resulting in a $0.59 \AA$ displacement of each of the disordered atoms. O21 and $\mathrm{O} 23$ were refined with an occupancy parameter equal to $\mathrm{x}$ (O22 occupancy = $0.5 x$ ) whereas $\mathrm{O} 21^{\prime}$ and $\mathrm{O}_{23}^{\prime}$ were refined with an occupancy parameter of $1-x\left[\mathrm{O} 22^{\prime}\right.$ occupancy $\left.=(1-x) / 2\right]$. The refined value of $x$ is 0.46 (3). Anisotropic displacement parameters for pairs of close atoms $\left(\mathrm{O} 21 / \mathrm{O}_{2} 1^{\prime}, \mathrm{O} 22 / \mathrm{O} 22^{\prime}\right.$ and $\left.\mathrm{O} 23 / \mathrm{O} 23^{\prime}\right)$ were constrained to identical values for each pair. The identity of the $\mathrm{Si}$ atom was confirmed by observing that the occupancy parameter refined to the correct value (0.5), confirming the electron density of the position, by comparing the $\mathrm{Si}-\mathrm{O}$ distances with those of the literature and by observing the charge neutrality of the structure which requires a +4 cation in that position.

Data collection: XSCANS (Siemens, 1991); cell refinement: $X S C A N S$; data reduction: XSCANS; program(s) used to solve structure: SHELXS97 (Sheldrick, 1990); $\operatorname{program}(\mathrm{s})$ used to refine structure: SHELXL97 (Sheldrick, 1997); molecular graphics: XP (Siemens, 1990); software used to prepare material for publication: SHELXL97.

JB acknowledges the support of the Moroccan-American Commission in the form of a Fullbright grant which has made this research possible.

\section{References}

Brown, I. D. (1981). Struct. Bonding Cryst. 2, 1-30.

Fukuoka, H., Imoto, H. \& Sato, T. (1996). J. Solid State Chem. 121, 247-250.

Leclaire, A., Chahboun, H., Groult, D. \& Raveau, B. (1986). J. Solid State Chem. 65, 168-177.

Leclaire, A., Lamire, M. \& Raveau, B. (1988). Acta Cryst. C44, 1181-1184. Leclaire, A. \& Raveau, B. (1987). J. Solid State Chem. 71, 283-290.

Sheldrick, G. M. (1990). Acta Cryst. A46, 467-473.

Sheldrick, G. M. (1997). SHELXL97. University of Göttingen, Germany.

Siemens (1990). XP. Version 4.1. Siemens Analytical X-ray Instruments Inc., Madison, Wisconsin, USA.

Siemens (1991). XSCANS Users Manual. Siemens Analytical X-ray Instruments, Inc., Madison, Wisconsin, USA.

Wang, S. L., Wang, C. C. \& Lii, K. H. (1988). J. Solid State Chem. 74, 409-413. 


\section{supporting information}

Acta Cryst. (2001). E57, i12-i14 [doi:10.1107/S1600536801001519]

\section{Dieuropium(III) silicodimonophosphatediphosphate}

\section{Jamal Bennazha, Ali Boukhari and Elizabeth M. Holt}

\section{S1. Comment}

The structural literature contains reports of only three silicophosphate materials with +3 charged cations. These contain two distinctly different silicophosphate moieties.

$\mathrm{RuSiP}_{3} \mathrm{O}_{11}$ (Fukuoka et al., 1996) may be seen to exist with $\mathrm{Si}_{2} \mathrm{O}_{7}$ groups sharing each of its six terminal $\mathrm{O}$ atoms with a different $\mathrm{P}_{2} \mathrm{O}_{7}$ group. Each $\mathrm{P}_{2} \mathrm{O}_{7}$ group is seen to share a single $\mathrm{O}$ atom per $\mathrm{PO}_{4}$ tetrahedron, with an $\mathrm{Si}_{2} \mathrm{O}_{7}$ group creating a three-dimensional network of linked tetrahedra which encapsulate $\mathrm{Ru}^{+3}$ cations. $\mathrm{MoSiP}_{3} \mathrm{O}_{11}$ (Leclaire \& Raveau, 1987) shows the same motif, with $\mathrm{Mo}^{+3}$ encapsulated within the three-dimensional network of silicophosphates.

$\mathrm{Mo}_{3} \mathrm{SiP}_{5} \mathrm{O}_{19}$ (Wang et al., 1988) exists with isolated $\left(\mathrm{PO}_{3} \mathrm{O}\right)_{3} \mathrm{SiOSi}\left(\mathrm{OPO}_{3}\right)_{3}$ and $\left(\mathrm{PO}_{3} \mathrm{O}\right)_{3} \mathrm{POP}\left(\mathrm{OPO}_{3}\right)_{3}$ units stacked in columns parallel to the hexagonal $c$ axis. $\mathrm{V}_{3} \mathrm{SiP}_{5} \mathrm{O}_{19}$ (Leclaire et al., 1986) appears to be isostructural with the molybedenum-containing compound of similar formula. $\mathrm{Mo}_{4} \mathrm{Si}_{2} \mathrm{P}_{6} \mathrm{O}_{25}$ (Leclaire et al., 1988) shows a similar motif but with $\left(\mathrm{PO}_{3} \mathrm{O}\right)_{3} \mathrm{SiOSi}\left(\mathrm{OPO}_{3}\right)_{3}$ groups only.

$\mathrm{Eu}_{2} \mathrm{Si}\left(\mathrm{PO}_{4}\right)_{2}\left(\mathrm{P}_{2} \mathrm{O}_{7}\right)$ crystallizes with silicophosphate chains with $\mathrm{Si}-\mathrm{O}-\mathrm{P}-\mathrm{O}-\mathrm{P}-\mathrm{O}$ backbones extending in the a direction (Fig. 1). Tetrahedral silicon is further bound to two monophosphate groups, whereas the $\mathrm{P}$ atoms of the polymeric chain are further bonded to two terminal $\mathrm{O}$ atoms, $\mathrm{O} 21$ and $\mathrm{O} 23$ (Fig. 1). Thus, it is a silicophosphate of a previously unseen type.

Atoms $\mathrm{O} 21, \mathrm{O} 22$ and $\mathrm{O} 23$ display a $0.455 / 0.545$ disorder with positions $\mathrm{O}_{21}^{\prime}, \mathrm{O} 22^{\prime}$ and $\mathrm{O} 23^{\prime}$, and are related to them by a $23.3^{\circ}$ rotation about the $\mathrm{P} 2-\mathrm{O} 24$ bond (Fig. 2). Atom $\mathrm{O} 22$ and $\mathrm{O} 22^{\prime}$ lie on a twofold axis.

$\mathrm{Eu}$ atoms are localized between $\mathrm{PO}_{3}$ groups and the two terminal $\mathrm{O}$ atoms of a $\mathrm{P}$ atom of the polymeric chain. Eu is within bonding distance of each of the disordered positions, $\mathrm{O} 21, \mathrm{O} 21^{\prime}, \mathrm{O} 23$ and $\mathrm{O} 23^{\prime}$. Eu ${ }^{\mathrm{III}}$ is six coordinate [average Eu

$-\mathrm{O} 2.317$ (6) $\AA$, with a seventh $\mathrm{Eu}-\mathrm{O}$ distance of 2.544 (5) $\AA$. With the inclusion of the seventh distance, the geometry at europium appears to be that of a pentagonal bipyramid. Using bond-valence calculations to ascertain the validity of the seventh distance (Brown, 1981) leads to a valence bond total of 3.065 using the six $\mathrm{Eu}-\mathrm{O}$ distances of less than 2.451 (5) $\AA$, but a significantly larger total of $3.352 \AA$ if the seventh distance is included. Both geometry and valencebond calculations argue that this longer distance is meaningful.

Silicon displays tetrahedral geometry, with an average $\mathrm{Si}-\mathrm{O}$ distance of 1.604 (5) $\AA$. Phosphorous tetrahedra have average $\mathrm{P}-\mathrm{O}$ distances of 1.511 (11) $\AA$.

\section{S2. Refinement}

The orthorhombic cell displayed absences $\mathrm{h} 00, \mathrm{~h}=2 \mathrm{n}$ and $0 \mathrm{k} 0, \mathrm{k}=2 \mathrm{n}$, fixing the space group as $P 2{ }_{1}{ }_{2} 2$. Disorder of three $\mathrm{O}$ atoms became apparent as refinement progressed. The $\mathrm{P}_{2} \mathrm{O}_{7}$ group exists with a twofold axis passing through the bridging $\mathrm{O}$ atom, which was seen to exist in two positions $\mathrm{O} 22$ and $\mathrm{O} 22^{\prime}$, both on the twofold axis. While $\mathrm{P} 2$ and $\mathrm{O} 24$ were seen in ordered positions, alternate or disordered positions were seen for terminal $\mathrm{O}$ atoms $\mathrm{O} 21$ (O21') and $\mathrm{O} 23$ $\left(\mathrm{O} 23^{\prime}\right)$. O21, O22, $\mathrm{O} 23$ and $\mathrm{O} 24$ form a tetrahedral array about $\mathrm{P} 2$ as do $\mathrm{O} 21^{\prime}, \mathrm{O} 22^{\prime} \mathrm{O} 23^{\prime}$ and $\mathrm{O} 24$. The disorder may be 
understood in terms of an approximately $22^{\circ}$ rotation about the $\mathrm{P} 2-\mathrm{O} 24$ (and the $\mathrm{P} 2 \mathrm{a}-\mathrm{O} 24 a$ bond related by the twofold axis) corresponding to the bridging $\mathrm{O}$ atom being 'up' or 'down' and resulting in a $0.59 \AA$ displacement of each of the disordered atoms. $\mathrm{O} 21$ and $\mathrm{O} 23$ were refined with an occupancy parameter equal to $x(\mathrm{O} 22$ occupancy $=0.5 \mathrm{x})$ whereas $\mathrm{O} 21^{\prime}$ and $\mathrm{O} 23^{\prime}$ were refined with an occupancy parameter of $1-x\left[\mathrm{O} 22^{\prime}\right.$ occupancy $\left.=(1-x) / 2\right]$. The refined value of $x$ is 0.46 (3). Anisotropic displacement parameters for pairs of close atoms (O21/O21', O22/O22' and O23/O23') were constrained to identical values for each pair. The identity of the Si atom was confirmed by observing that the occupancy parameter refined to the correct value (1/2), confirming the electron density of the position, by comparing the $\mathrm{Si}-\mathrm{O}$ distances with those of the literature and by observing the charge neutrality of the structure which requires a +4 cation in that position.

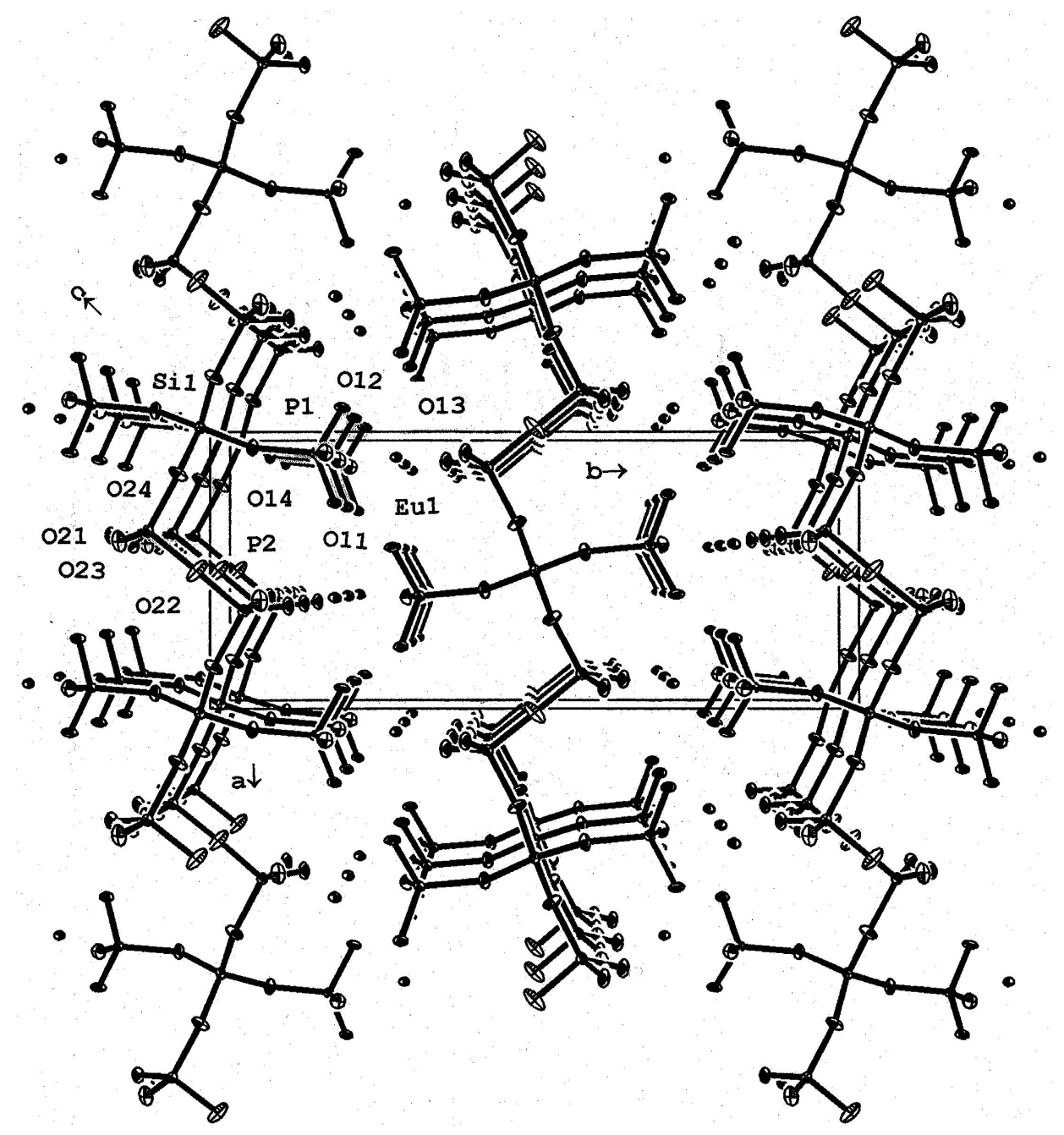

Figure 1

View of dieuropium(III) silicodimonophosphatediphosphate projected on the $a b$ plane. Displacement ellipsoids are shown at the $50 \%$ probability level. 


\section{Dieuropium(III) silicodimonophosphatediphosphate}

Crystal data

$\mathrm{Eu}_{2} \mathrm{Si}\left(\mathrm{PO}_{4}\right)_{2}\left(\mathrm{P}_{2} \mathrm{O}_{7}\right)$

$M_{r}=695.90$

Orthorhombic, $P 22_{1} 22$

$a=7.056(1) \AA$

$b=16.376(3) \AA$

$c=5.585(1) \AA$

$V=645.34(19) \AA^{3}$

$Z=2$

$F(000)=640$

\section{Data collection}

Syntex P4 four-circle diffractometer

Radiation source: fine-focus sealed tube

Graphite monochromator

$\theta / 2 \theta$ scans

Absorption correction: $\psi$ scan

(XEMP; Siemens, 1990)

$T_{\min }=0.181, T_{\max }=0.357$

1578 measured reflections

\section{Refinement}

Refinement on $F^{2}$

Least-squares matrix: full

$R\left[F^{2}>2 \sigma\left(F^{2}\right)\right]=0.025$

$w R\left(F^{2}\right)=0.064$

$S=1.07$

1422 reflections

111 parameters

1 restraint

Primary atom site location: structure-invariant direct methods
$D_{\mathrm{x}}=3.581 \mathrm{Mg} \mathrm{m}^{-3}$

Mo $K \alpha$ radiation, $\lambda=0.71073 \AA$

Cell parameters from 24 reflections

$\theta=5.6-16.9^{\circ}$

$\mu=10.30 \mathrm{~mm}^{-1}$

$T=293 \mathrm{~K}$

Needle, colorless

$0.15 \times 0.12 \times 0.1 \mathrm{~mm}$

1422 independent reflections

1388 reflections with $I>2 \sigma(I)$

$R_{\text {int }}=0.031$

$\theta_{\max }=30.0^{\circ}, \theta_{\min }=2.5^{\circ}$

$h=-1 \rightarrow 9$

$k=-1 \rightarrow 23$

$l=-1 \rightarrow 7$

3 standard reflections every 97 reflections

intensity decay: $0.0 \%$

Secondary atom site location: difference Fourier map

$w=1 /\left[\sigma^{2}\left(F_{\mathrm{o}}^{2}\right)+(0.0334 P)^{2}+1.2737 P\right]$

where $P=\left(F_{\mathrm{o}}{ }^{2}+2 F_{\mathrm{c}}{ }^{2}\right) / 3$

$(\Delta / \sigma)_{\max }=0.012$

$\Delta \rho_{\max }=0.01 \mathrm{e} \AA^{-3}$

$\Delta \rho_{\min }=-0.02$ e $\AA^{-3}$

Extinction correction: SHELXL97,

$\mathrm{Fc}^{*}=\mathrm{kFc}\left[1+0.001 \mathrm{xFc}^{2} \lambda^{3} / \sin (2 \theta)\right]^{-1 / 4}$

Extinction coefficient: 0.0030 (4)

\section{Special details}

Geometry. All e.s.d.'s (except the e.s.d. in the dihedral angle between two 1.s. planes) are estimated using the full covariance matrix. The cell e.s.d.'s are taken into account individually in the estimation of e.s.d.'s in distances, angles and torsion angles; correlations between e.s.d.'s in cell parameters are only used when they are defined by crystal symmetry. An approximate (isotropic) treatment of cell e.s.d.'s is used for estimating e.s.d.'s involving 1.s. planes.

Refinement. Refinement of $F^{2}$ against ALL reflections. The weighted $R$-factor $w R$ and goodness of fit $S$ are based on $F^{2}$, conventional $R$-factors $R$ are based on $F$, with $F$ set to zero for negative $F^{2}$. The threshold expression of $F^{2}>\sigma\left(F^{2}\right)$ is used only for calculating $R$-factors(gt) etc. and is not relevant to the choice of reflections for refinement. $R$-factors based on $F^{2}$ are statistically about twice as large as those based on $F$, and $R$ - factors based on ALL data will be even larger.

Fractional atomic coordinates and isotropic or equivalent isotropic displacement parameters $\left(\AA^{2}\right)$

\begin{tabular}{llllll}
\hline & $x$ & $y$ & $z$ & $U_{\text {iso }} * U_{\text {eq }}$ & Occ. $(<1)$ \\
\hline Eu1 & $0.08893(4)$ & $0.284646(19)$ & $0.86217(6)$ & $0.01108(10)$ & \\
Si1 & 0.0000 & 0.0000 & $1.4557(5)$ & $0.0133(5)$ & \\
P1 & $0.0855(2)$ & $0.16894(9)$ & $1.3063(3)$ & $0.0112(3)$ & \\
O11 & $0.2587(6)$ & $0.1945(3)$ & $1.1648(10)$ & $0.0167(10)$ &
\end{tabular}




\begin{tabular}{|c|c|c|c|c|c|}
\hline $\mathrm{O} 12$ & $-0.0798(6)$ & $0.2069(3)$ & $1.1706(9)$ & $0.0188(10)$ & \\
\hline $\mathrm{O} 13$ & $0.0651(8)$ & $0.0734(3)$ & $1.2809(9)$ & $0.0190(10)$ & \\
\hline $\mathrm{O} 14$ & $0.0910(9)$ & $0.1889(3)$ & $1.5690(9)$ & $0.0216(10)$ & \\
\hline P2 & $0.3633(2)$ & $-0.07078(10)$ & $1.6411(4)$ & $0.0134(3)$ & \\
\hline $\mathrm{O} 21$ & 0.378 & $-0.1316(9)$ & $1.447(4)$ & $0.025(2)$ & $0.455(12)$ \\
\hline $\mathrm{O} 21^{\prime}$ & $0.407(2)$ & $-0.1026(7)$ & $1.396(3)$ & $0.025(2)$ & $0.545(12)$ \\
\hline $\mathrm{O} 22$ & 0.5000 & 0.0000 & $1.589(5)$ & 0.039 (3) & $0.455(12)$ \\
\hline $\mathrm{O} 22^{\prime}$ & 0.5000 & 0.0000 & $1.703(4)$ & 0.039 & $0.545(12)$ \\
\hline $\mathrm{O} 23$ & 0.400 & $-0.1017(9)$ & $1.893(3)$ & $0.026(2)$ & $0.455(12)$ \\
\hline O23' & $0.361(2)$ & $-0.1278(8)$ & $1.836(2)$ & $0.026(2)$ & $0.545(12)$ \\
\hline $\mathrm{O} 24$ & $0.1666(7)$ & $-0.0263(3)$ & $1.6321(11)$ & $0.0244(11)$ & \\
\hline
\end{tabular}

Atomic displacement parameters $\left(\AA^{2}\right)$

\begin{tabular}{lllllll}
\hline & $U^{11}$ & $U^{22}$ & $U^{33}$ & $U^{12}$ & $U^{13}$ & $U^{23}$ \\
\hline Eu1 & $0.00969(13)$ & $0.01415(14)$ & $0.00939(14)$ & $-0.00079(12)$ & $-0.00027(12)$ & $0.00019(13)$ \\
Si1 & $0.0139(11)$ & $0.0104(10)$ & $0.0155(12)$ & $0.0008(9)$ & 0.000 & 0.000 \\
P1 & $0.0109(6)$ & $0.0115(6)$ & $0.0110(7)$ & $-0.0013(6)$ & $-0.0004(6)$ & $0.0010(5)$ \\
O11 & $0.0101(18)$ & $0.021(2)$ & $0.019(2)$ & $0.0008(16)$ & $-0.002(2)$ & $0.0089(19)$ \\
O12 & $0.0083(17)$ & $0.025(2)$ & $0.023(2)$ & $0.002(2)$ & $-0.002(2)$ & $0.008(2)$ \\
O13 & $0.028(3)$ & $0.0118(19)$ & $0.017(2)$ & $-0.0018(19)$ & $0.006(2)$ & $-0.0021(18)$ \\
O14 & $0.025(2)$ & $0.024(2)$ & $0.016(2)$ & $0.000(2)$ & $0.000(3)$ & $-0.005(2)$ \\
P2 & $0.0131(7)$ & $0.0120(6)$ & $0.0150(7)$ & $-0.0005(5)$ & $-0.0008(7)$ & $-0.0005(7)$ \\
O21 & $0.032(5)$ & $0.013(6)$ & $0.030(6)$ & $0.002(5)$ & $-0.009(5)$ & $-0.012(5)$ \\
O21' & $0.032(5)$ & $0.013(6)$ & $0.030(6)$ & $0.002(5)$ & $-0.009(5)$ & $-0.012(5)$ \\
O22 & $0.045(6)$ & $0.042(6)$ & $0.029(8)$ & $-0.030(5)$ & 0.000 & 0.000 \\
O22' & $0.045(6)$ & $0.042(6)$ & $0.029(8)$ & $-0.030(5)$ & 0.000 & 0.000 \\
O23 & $0.045(6)$ & $0.021(6)$ & $0.011(5)$ & $0.003(5)$ & $-0.011(4)$ & $0.006(4)$ \\
O23' & $0.045(6)$ & $0.021(6)$ & $0.011(5)$ & $0.003(5)$ & $-0.011(4)$ & $0.006(4)$ \\
O24 & $0.020(2)$ & $0.032(3)$ & $0.022(3)$ & $0.012(2)$ & $-0.006(3)$ & $-0.003(3)$ \\
& & & & & & \\
\hline
\end{tabular}

Geometric parameters $\left(\AA,{ }^{\circ}\right)$

\begin{tabular}{|c|c|c|c|}
\hline $\mathrm{Eu} 1-\mathrm{O} 21^{\mathrm{i}}$ & $2.217(18)$ & $\mathrm{Si} 1-\mathrm{O} 13$ & $1.615(5)$ \\
\hline $\mathrm{Eu} 1-\mathrm{O} 21^{\prime \mathrm{i}}$ & $2.344(13)$ & $\mathrm{P} 1-\mathrm{O} 11$ & $1.514(5)$ \\
\hline $\mathrm{Eu} 1-\mathrm{O} 23^{\mathrm{ii}}$ & $2.309(15)$ & $\mathrm{P} 1-\mathrm{O} 12$ & $1.523(5)$ \\
\hline $\mathrm{Eu} 1-\mathrm{O} 23^{\prime \text { ii }}$ & $2.240(12)$ & $\mathrm{P} 1-\mathrm{O} 13$ & $1.577(5)$ \\
\hline Eu1-O14iii & $2.267(5)$ & $\mathrm{P} 1-\mathrm{O} 14$ & $1.504(5)$ \\
\hline $\mathrm{Eu} 1-\mathrm{O} 12^{\mathrm{iv}}$ & $2.349(4)$ & $\mathrm{P} 2-\mathrm{O} 21$ & $1.476(18)$ \\
\hline $\mathrm{Eu} 1-\mathrm{O} 11^{\mathrm{v}}$ & $2.360(4)$ & $\mathrm{P} 2-\mathrm{O} 21^{\prime}$ & $1.496(15)$ \\
\hline $\mathrm{Eu} 1-\mathrm{O} 12$ & $2.451(5)$ & $\mathrm{P} 2-\mathrm{O} 22$ & $1.536(5)$ \\
\hline $\mathrm{Eu} 1-\mathrm{O} 11$ & $2.544(5)$ & $\mathrm{P} 2-\mathrm{O} 22^{\prime}$ & $1.547(5)$ \\
\hline $\mathrm{Si} 1-\mathrm{O} 24$ & $1.593(6)$ & $\mathrm{P} 2-\mathrm{O} 23$ & $1.520(14)$ \\
\hline $\mathrm{Si} 1-\mathrm{O} 24^{\mathrm{vi}}$ & $1.593(6)$ & $\mathrm{P} 2-\mathrm{O} 23^{\prime}$ & $1.436(12)$ \\
\hline Sil-O13 ${ }^{\text {vi }}$ & $1.615(5)$ & $\mathrm{P} 2-\mathrm{O} 24$ & $1.568(5)$ \\
\hline $\mathrm{O} 21^{\mathrm{i}}-\mathrm{Eu} 1-\mathrm{O} 14^{\mathrm{iii}}$ & $82.2(5)$ & $\mathrm{O} 21^{\prime \mathrm{i}}-\mathrm{Eu} 1-\mathrm{O} 11$ & $149.4(4)$ \\
\hline 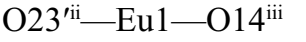 & $169.9(4)$ & $\mathrm{O} 12-\mathrm{Eu} 1-\mathrm{O} 11$ & $57.32(14)$ \\
\hline
\end{tabular}




\begin{tabular}{|c|c|c|c|}
\hline $\mathrm{O} 21^{\mathrm{i}}-\mathrm{Eu} 1-\mathrm{O} 23^{\mathrm{ii}}$ & $87.6(5)$ & $\mathrm{O} 24-\mathrm{Si} 1-\mathrm{O} 24^{\mathrm{vi}}$ & $103.6(5)$ \\
\hline $\mathrm{O} 14^{\mathrm{iii}}-\mathrm{Eu} 1-\mathrm{O} 23^{\mathrm{ii}}$ & $169.7(4)$ & $\mathrm{O} 24-\mathrm{Si} 1-\mathrm{O} 13^{\mathrm{vi}}$ & $112.5(3)$ \\
\hline $\mathrm{O} 21^{\mathrm{i}}-\mathrm{Eu} 1-\mathrm{O} 12^{\mathrm{iv}}$ & $78.4(5)$ & $\mathrm{O} 24^{\mathrm{vi}}-\mathrm{Si} 1-\mathrm{O} 13^{\mathrm{vi}}$ & $111.4(3)$ \\
\hline 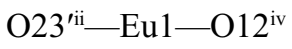 & $82.1(4)$ & $\mathrm{O} 24-\mathrm{Si} 1-\mathrm{O} 13$ & $111.4(3)$ \\
\hline $\mathrm{O} 14^{\mathrm{iii}}-\mathrm{Eu} 1-\mathrm{O} 12^{\mathrm{iv}}$ & $88.8(2)$ & $\mathrm{O} 24^{\mathrm{vi}}-\mathrm{Si} 1-\mathrm{O} 13$ & $112.5(3)$ \\
\hline $\mathrm{O} 23^{\mathrm{ii}}-\mathrm{Eu} 1-\mathrm{O} 12^{\mathrm{iv}}$ & $88.0(5)$ & $\mathrm{O} 13^{\mathrm{vi}}-\mathrm{Si} 1-\mathrm{O} 13$ & $105.6(4)$ \\
\hline 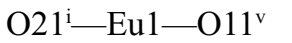 & $87.9(5)$ & $\mathrm{O} 14-\mathrm{P} 1-\mathrm{O} 11$ & $115.4(3)$ \\
\hline $\mathrm{O} 23^{\prime \text { ii }-E u 1-O} 11^{v}$ & $96.4(4)$ & $\mathrm{O} 14-\mathrm{P} 1-\mathrm{O} 12$ & $114.6(3)$ \\
\hline 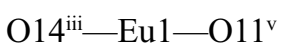 & $93.5(2)$ & $\mathrm{O} 11-\mathrm{P} 1-\mathrm{O} 12$ & $104.2(3)$ \\
\hline $\mathrm{O} 23^{\mathrm{ii}}-\mathrm{Eu} 1-\mathrm{O} 11^{\mathrm{v}}$ & $87.4(5)$ & $\mathrm{O} 14-\mathrm{P} 1-\mathrm{O} 13$ & $107.8(3)$ \\
\hline $\mathrm{O} 12^{\mathrm{iv}}-\mathrm{Eu} 1-\mathrm{O} 11^{\mathrm{v}}$ & $165.72(15)$ & $\mathrm{O} 11-\mathrm{P} 1-\mathrm{O} 13$ & $107.5(3)$ \\
\hline 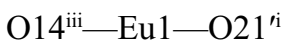 & $95.7(4)$ & $\mathrm{O} 12-\mathrm{P} 1-\mathrm{O} 13$ & $106.8(3)$ \\
\hline $\mathrm{O} 12^{\mathrm{iv}}-\mathrm{Eu} 1-\mathrm{O} 21^{\prime \mathrm{i}}$ & 83.9 (4) & $\mathrm{O} 21-\mathrm{P} 2-\mathrm{O} 23$ & $116.4(8)$ \\
\hline $\mathrm{O} 11^{\mathrm{v}}-\mathrm{Eu} 1-\mathrm{O} 21^{\prime \mathrm{i}}$ & $81.9(4)$ & $\mathrm{O} 21-\mathrm{P} 2-\mathrm{O} 22$ & $108.9(10)$ \\
\hline 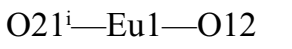 & $156.9(5)$ & $\mathrm{O} 23-\mathrm{P} 2-\mathrm{O} 22$ & $108.8(11)$ \\
\hline O23 $3^{\prime i i}-\mathrm{Eu} 1-\mathrm{O} 12$ & $83.2(4)$ & $\mathrm{O} 21-\mathrm{P} 2-\mathrm{O} 24$ & $110.7(8)$ \\
\hline $\mathrm{O} 14 \mathrm{iii}-\mathrm{Eu} 1-\mathrm{O} 12$ & $98.71(18)$ & $\mathrm{O} 23-\mathrm{P} 2-\mathrm{O} 24$ & $109.6(8)$ \\
\hline $\mathrm{O} 23^{\mathrm{ii}}-\mathrm{E} u 1-\mathrm{O} 12$ & $91.1(4)$ & $\mathrm{O} 22-\mathrm{P} 2-\mathrm{O} 24$ & $101.5(2)$ \\
\hline $\mathrm{O} 12^{\mathrm{iv}}-\mathrm{Eu} 1-\mathrm{O} 12$ & $124.68(12)$ & $\mathrm{O} 23^{\prime}-\mathrm{P} 2-\mathrm{O} 22^{\prime}$ & $109.0(9)$ \\
\hline $\mathrm{O} 11^{\mathrm{v}}-\mathrm{Eu} 1-\mathrm{O} 12$ & $68.94(15)$ & $\mathrm{O} 21^{\prime}-\mathrm{P} 2-\mathrm{O} 22^{\prime}$ & $109.7(9)$ \\
\hline $\mathrm{O} 21^{\prime i}-\mathrm{Eu} 1-\mathrm{O} 12$ & $148.0(4)$ & $\mathrm{O} 23^{\prime}-\mathrm{P} 2-\mathrm{O} 24$ & $108.4(6)$ \\
\hline 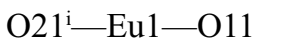 & $145.8(5)$ & $\mathrm{O} 23^{\prime}-\mathrm{P} 2-\mathrm{O} 21^{\prime}$ & $118.1(7)$ \\
\hline 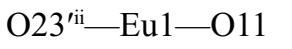 & $78.3(4)$ & $\mathrm{O} 21^{\prime}-\mathrm{P} 2-\mathrm{O} 24$ & $108.4(6)$ \\
\hline $\mathrm{O} 14^{\mathrm{iii}}-\mathrm{Eu} 1-\mathrm{O} 11$ & $94.34(18)$ & $\mathrm{O} 22^{\prime}-\mathrm{P} 2-\mathrm{O} 24$ & $102.2(2)$ \\
\hline $\mathrm{O} 23^{\mathrm{ii}}-\mathrm{Eu} 1-\mathrm{O} 11$ & $93.4(4)$ & $\mathrm{P} 2^{\mathrm{vii}}-\mathrm{O} 22-\mathrm{P} 2$ & $158(2)$ \\
\hline $\mathrm{O} 12^{\mathrm{iv}}-\mathrm{Eu} 1-\mathrm{O} 11$ & $67.52(15)$ & $\mathrm{P} 2-\mathrm{O} 22^{\prime}-\mathrm{P} 2^{\mathrm{vii}}$ & $154.1(16)$ \\
\hline $\mathrm{O} 11^{\mathrm{v}}-\mathrm{Eu} 1-\mathrm{O} 11$ & $126.26(12)$ & & \\
\hline
\end{tabular}

Symmetry codes: (i) $-x+1 / 2, y+1 / 2,-z+2$; (ii) $-x+1 / 2, y+1 / 2,-z+3$; (iii) $x, y, z-1$; (iv) $x+1 / 2,-y+1 / 2,-z+2$; (v) $x-1 / 2,-y+1 / 2,-z+2$; (vi) $-x,-y, z$; (vii) $-x+1,-y, z$. 